\title{
Visualidade e inventividade na obra de Ana Hatherly
}

Resumo: $\mathrm{O}$ artigo pretende discutir a respeito da visualidade na obra de Ana Hatherly através da plagiotropia, tanto nos textos poéticos como ensaísticos. Trata-se de um procedimento experiemental essencial para a sua revisitação ao barroco português dos séculos XVII e XVIII.

Palavras-chave: experimentalismo, barroco, plagiotropia

Abstract: The article intends to discuss the visuality in the work of Ana Hatherly through plagiotropia, both in poetic and essayistic texts. It is an essencial experimental procedure for her revisitation to Portuguese baroque of the 17 th and 18 th centuries.

Keywords: experimentalism, baroque, plagiotropia

Sem entrega não há criação.

Ana Hatherly

A plagiotropia na poesia de Ana Hatherly é um jogo barroco textual e transtextual, pois excede o limite da palavra e vai se encaminhando para o campo da visualidade através da pintura e dos grafismos. A autora trabalha escrituralmente e pictoricamente com o mesmo rigor técnico, explorando os limites da palavra enquanto pintura e pintura enquanto palavra. Pode-se estabelecer uma tríade que engloba o grafismo, a pintura e a palavra, sendo que a escrita e o grafismo subdividem-se, de um lado temos um artesanato, mas de outro a pintura como um gesto materializado em uma tela. Contemporaneamente, esse campo de experimentação se alarga para o recorte e para a colagem, ou décollage,

que consiste numa espécie de mutação radical da collage, onde a superfície plástica é composta a partir de fragmentos de imagens e textos extraídos do espaço urbano, por meio 
de um gesto que carrega consigo uma voltagem potencialmente mais alta do que a precisão cirúrgica no corte para a collage. (Salgado 2015: 131-132)

Esse aspecto fora destacado por Marcus Rogério Salgado, no ensaio As metamorfoses da escrita: Constelações de palavras e imagens na obra plástica de Ana Hatherly. A décollage surge da plasticidade e materialidade da poesia, fazendo com que haja um forte intercâmbio interartístico, que passa pelas origens do grafismo e da poesia visual até o recorte e colagem, que por sua vez são trazidos para o âmbito da palavra. Estas são as bases da composição de suas obras, que criam um elo da poeta com os escritores que quis homenagear, por meio do diálogo que sua obra estabelece entre eles. Tal ferramenta pode ser melhor compreendida, por exemplo, pela coleção As ruas de Lisboa (1977) ${ }^{1}$ :
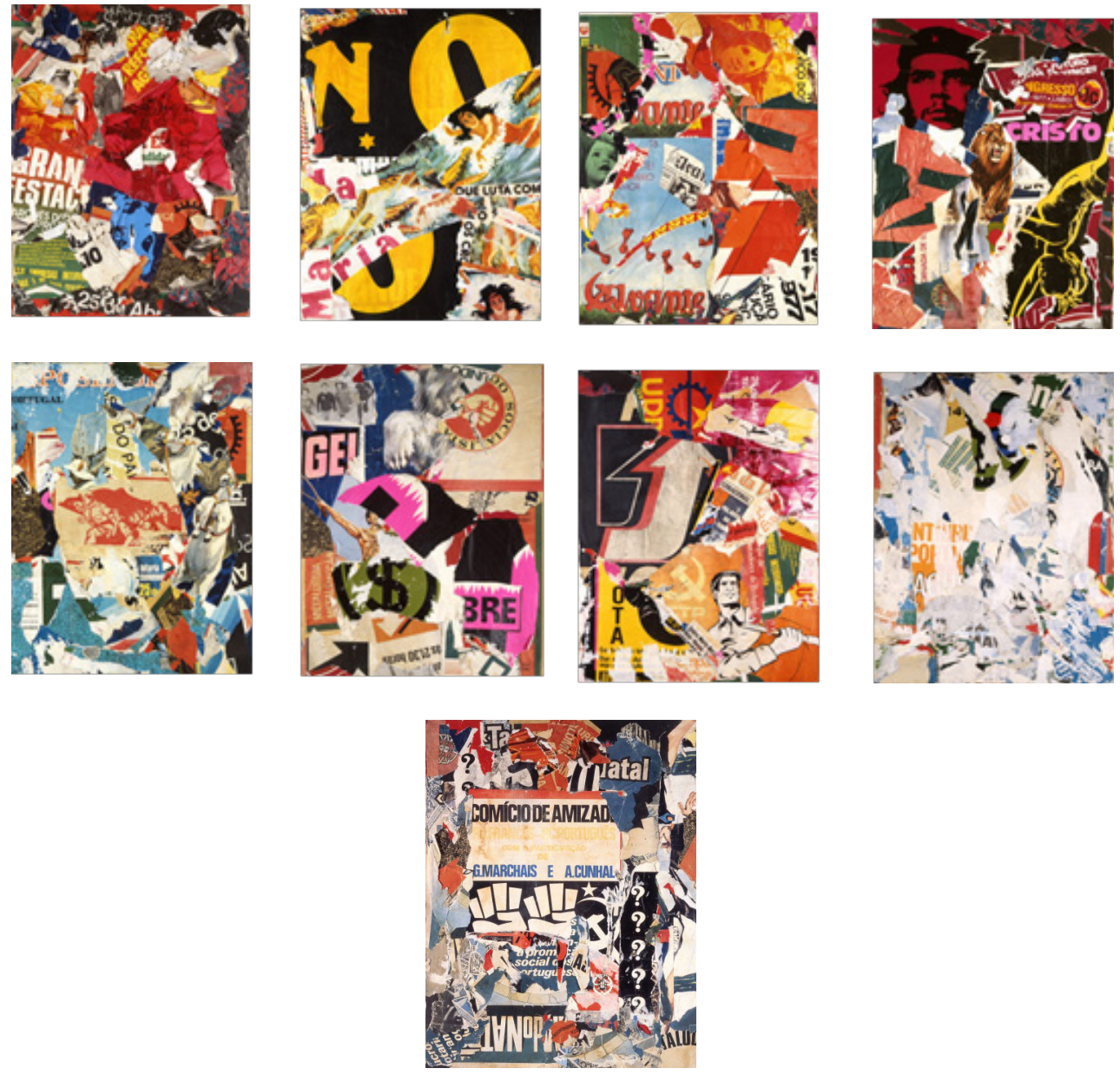

Coleção As ruas de Lisboa (1977) 
Como Rilkeana é uma publicação de 1999, esse recurso também é compreendido substancialmente como citação. Segundo Antoine Compagnon, "Recorte e colagem são as experiências fundamentais com o papel, das quais a leitura e a escrita não são senão formas derivadas, transitórias, efêmeras" (Compagnon 1996: 11). Compagnon soma o processo de recorte e colagem ao ato de escrita e leitura. Se fizermos uma comparação entre Companhon e Ana Hatherly enquanto teórica, chegaremos à conclusão de que os procedimentos de composição são fundamentais para a poética contemporânea, que consiste na mesclagem de materiais diversificados que dão plasticidade ao signo verbal, e não é diferente a concordância entre ambos, que "O texto é a prática do papel." (idem: 12).

\title{
Barroco: um jogo plagiotrópico
}

\author{
A nossa tarefa é entender o mundo \\ diziam os antigos \\ já sabiam \\ que o jogo somos nós \\ (the toy are us) \\ Ana Hatherly (Fibrilações, 2005)
}

O texto como prática do papel nos incita a ir mais a fundo nos procedimentos poéticos de Ana Hatherly, principalmente no que respeita à revisitação do Barroco. Ainda com Compagnon podemos partir de mais uma citação sua, sobre a apropriação, "em que o sujeito parte em busca de si mesmo como de um outro, à procura de sua identidade entre os objetos que o circundam" (Compagnon 1996: 147). Esta afirmação permite identificar que a busca pelo objeto de desejo, também ocorre na forma do poema, que traça um caminho visual percorrido nas variações elegíacas. Em entrevista a Maria Augusta Silva, Hatherly faz a seguinte declaração: "Eu reinvento através de um processo de questionação sistemática que acaba por ser favorável ao elemento analisado e não destruidor desse elemento. O texto que ofereço é a minha própria meditação sobre o tema que escolhi e vou glosar a meu modo" (Silva 2000: 4). Isto nos reforça a ideia de que a plagiotropia não possui relação com o plágio, mas se trata de uma apropriação, que permite a liberdade criadora, pela qual preza a poeta. Também é relevante considerar que a plagiotropia de que estamos tratando aproxima-se da premissa aristotélica de que "O imitar é congênito no homem (e nisso difere dos outros viventes, pois, de todos, é ele o mais imitador, e, por imitação, aprende as primeiras noções), e os homens se comprazem no imitado" (Aristóteles 2015: 35).

Existe aqui uma problemática, pois ao mesmo tempo em que a noção de imitação se associa à plagiotropia, temos a consciência de que são conceitos diferentes. Depreende-se que Aristóteles apresenta a imitação como reprodução literal, ao passo que a poeta 
realiza uma questionação sistemática das obras com as quais dialoga. Tal recurso é um exercício que dá concretude às inquietações da própria poeta. Nesse sentido, a noção de apropriação possui sua importância, considerando que este é um exercício de liberdade de escrita. Todavia, sugerir outras denominações para as experimentações de Ana Hatherly é um percurso sem fim, sendo preferível que nos detenhamos naquela escolhida por ela própria, identificada em uma tese publicada no Brasil nos anos 90, intitulada Outrora agora: relações dialógicas na poesia portuguesa de invenção, de Maria dos Prazeres Gomes:

Se se pudéssemos nomear o modo sui generis da invenção barroca, arriscaríamos chamá-lo plagiotropia. Convém repetir, para afastar as associações depreciativas, por plagiotropia entendemos o movimento de apropriação e transformação dos textos literários, "num sentido não necessariamente retilíneo", "numa derivação nem sempre imediata". Conforme Haroldo de Campos, que cunhou o termo, ela "encerra uma tentativa de descrição semiótica do processo literário como produto de revezamento contínuo de interpretantes, de uma "semiose ilimitada” ou 'infinita' (Pierce, Eco), que se desenrola no espaço cultural. (Gomes 1993: 193)

O ato de apropriação sempre esteve presente na literatura, mas Maria dos Prazeres insiste em afirmar que "Não se trata aqui de intertextualidade como princípio inerente à criação literária, mas de uma estratégia deliberadamente assumida em todos os seus desdobramentos, sejam de negação ou homologia" (Gomes 1993: 193). Na poética hatherliana, os diálogos são percebidos explicitamente pelos títulos dados aos livros e pelos motivos, que possibilitam ao leitor identificar pelas glosas quais marcas de outros autores estão presentes e que passam a integrar a tradição poética portuguesa. O leitor passa a conhecer a poesia de Ana Hatherly, mas também a obra de outros poetas, desafio intelectual que revela o seu domínio cultural, da tradição e do seu próprio programa poético, mantendo-se fiel ao que acredita, isto é, ao estilo barroco e ao que ensinou como professora, incitando à leitura de outros poetas através de um procedimento de leitura inovador, pois de acordo com Rogério Barbosa da Silva, leitor da poeta, "exemplar é a poesia e a crítica de Ana Hatherly, uma vez que tanto o seu trabalho criativo quanto o crítico buscam reinserir a tradição criativa em Portugal, isto é, reinventá-la, já que o passado só se atualiza na medida em que ele passe a significar pelo movimento da escrita e da leitura" (Silva 2011: 135).

A busca pelo objeto de desejo, o tema eleito por Hatherly, ocorre também na estrutura do poema, o que foi dito anteriormente, e que visualmente nos apresenta os versos dispostos em curvas direcionadas para a direita e retornando para onde se inicia a estrofe seguinte, conforme podemos ler na variação III-A: 


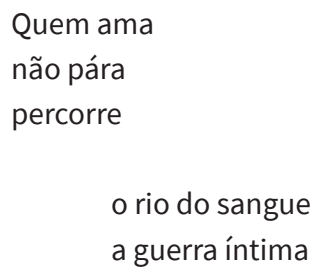

Não

nada nos pode consolar

do peso do amor

do peso do não-saber

do peso do divino

Transfigurados pelo desejo

fitamos as estrelas

deslumbrados

perscrutando

um brilho extinto

que a si próprio

se escava

e aplaina

(Hatherly 1999: 42)

Seguindo com os procedimentos utilizados por Ana Hatherly, fazemos imediatamente um retorno, pois a partir de agora falaremos sobre a Dobra barroca. O retorno se deve ao fato de que a dobra, integrante da estética arquitetônica do período barroco, vai se estender a outros campos, como a poesia, tanto no sentido estrutural como no plano do significado, como foi visto nas relações dialógicas com a poesia de Rainer Maria Rilke. Imergindo no pensamento deleuziano, consideramos com ele que "é a alma que tem dobras, que está cheia de dobras. As dobras estão na alma e só existem atualmente na alma" (Deleuze 2012: 45), pois tal pensamento nos auxilia na compreensão de que o barroco assim se expande no plano do significado da poesia de Ana Hatherly. Além da exterioridade presente na arquitetura daquele período, existe um interesse em adentrar às dobras e desdobras da alma que, de acordo com Gilles Deleuze, recairá em uma reflexão metafísica. Temos, assim, uma maleabilidade quanto à dobra, que é detectada no gesto criador de Hatherly. Deleuze introduz o livro A dobra: Leibniz e o barroco da seguinte forma:

O barroco remete não a uma essência, mas sobretudo a uma função operatória, a um traço. Não para de fazer dobras. Ele não inventou essa coisa: há todas as dobras vindas do Oriente, dobras gregas, romanas, românicas, góticas, clássicas... Mas ele curva e recurva as dobras, 
leva-as ao infinito, dobra sobre a dobra, dobra conforme a dobra. O traço do barroco é a dobra que vai ao infinito. Primeiramente, ele diferencia as dobras segundo duas direções, segundo dois infinitos, como se o infinito tivesse dois andares: redobras da matéria e as dobras na alma. Embaixo, a matéria é amontoada de acordo com um primeiro gênero de dobra, sendo, depois, organizada de acordo com um segundo gênero, uma vez que suas partes constituem órgãos "dobrados diferentemente e mais ou menos desenvolvidos". No alto, a alma canta a glória de Deus, uma vez que percorre suas próprias dobras, sem chegar a desenvolvê-las inteiramente, "pois elas vão ao infinito". Diz-se que um labirinto é múltiplo, etimologicamente, porque tem muitas dobras. O múltiplo não é só o que tem muitas partes, mas o que é dobrado de muitas maneiras. Um labirinto corresponde precisamente a cada andar: o labirinto do contínuo, na matéria e em suas partes, e o labirinto da liberdade, na alma e seus predicados. (Deleuze 2004: 13-14)

Ao fazer referência ao barroco, o filósofo o define primeiramente como um complexo arquitetônico, tendo por exemplo uma casa barroca de dois andares. A princípio, o andar inferior representa a materialidade que entra em complementaridade com o andar superior, que é uma extensão da inferioridade material, e representa a dobra ao infinito. A representação da casa barroca também é importante no pensamento de Deleuze por nos remeter também a outro traço barroco de relevância, que é o interior e o exterior. A partir daí, temos uma discussão metafísica à qual o filósofo adentra. Este fator é importante pois possibilita fazer aproximações com o trabalho de escrita de Rilke, em diálogo com Ana Hatherly, cujas escritas poéticas possuem tonalidades barrocas, que procuramos por em destaque nesta leitura.

Já a desdobra é também definida por Deleuze:

(...) a desdobra não é o contrário da dobra nem sua elisão, mas a continuação ou a extensão do seu ato, a condição de sua manifestação. Quando a dobra deixa de ser representada para tornar-se "método", operação, ato, a desdobra vem a ser o resultado do ato que se expressa precisamente dessa maneira. (Deleuze 2004: 68)

Este movimento nos é caro, pois relaciona-se às subvariações rilkeanas. Ao percebermos nestas um eco das variações, podemos compreendê-las igualmente como uma extensão. As subvariações estão imbuídas de um gesto contínuo de escrita e um prolongamento do sentido que os poemas expressam. Até então, temos em Rilkeana, pares dicotômicos que essencialmente são barrocos, como interioridade e exterioridade no gesto poético, contiguidade e expansividade na capacidade sintética da poeta, e a dobra e desdobra do sentido e da plasticidade, que estão no âmago dos poemas de Ana Hatherly.

Paulo Pereira, no ensaio As dobras da melancolia - o imaginário barroco português, nos contextualiza sobre o Barroco: 
Diz-se que o barroco é uma palavra de origem portuguesa. Os ourives portugueses, já em tempo de D. Manuel, chamavam às pérolas grandes e deformadas, barrocas. Barrocal ou barroca é também o nome que entre nós se dá aos agregados de pedras informes e arredondadas poderosos afloramentos de rochas metamórficas - muito comuns ao Norte de Portugal, na Estremadura e no Alentejo. (Pereira 1997: 160)

Historicamente, este período nos traz algumas formas emblemáticas que nos cabe destacar, como por exemplo, a concha, a elipse, os óculos, o homem no jardim e os anjos. Outras características são: as antíteses advindas do conflito entre essência e aparência, interior e exterior; o mundo como representação; o mundo como labirinto; a melancolia e o cosmopolitismo. Paulo Pereira acrescenta que:

A cosmovisão barroca portuguesa (e européia em geral) está intimamente ligada pela incerteza e instabilidade, em boa medida fundadas, sobretudo entre nós, numa situação de crise econômica, social e política (as grandes epidemias e fomes dos anos 30 de Seiscentos, a perda da independência, a guerra da Restauração e a falência comercial), fatos que não deixaram de influenciar uma duradoura axiologia, ela também instável, expressa ainda em pleno reinado de D. João V (o belo/feio, o feio/bom). (Pereira 1997: 165)

Do imaginário barroco pode-se retirar algumas aproximações com as Elegias de Rilke, que fazem o leitor experienciar os mesmos sentimentos de incerteza e instabilidade, como consequências contextuais experienciadas pelo poeta. Na Origem do drama trágico alemão, Walter Benjamin consegue identificar elementos aglutinadores entre o Barroco e o Romantismo alemão. Em nossa leitura, percebemos que existem traços barrocos na poesia em língua alemã. Elucida-nos Benjamin com as seguintes palavras: "Surpreendentes analogias com a situação atual da literatura alemã deram azo a um aprofundamento do Barroco, que, apesar de as mais das vezes ter uma orientação sentimental, é no geral positivo" (Benjamin 2013: 44). E destaca, mais adiante: "É próprio de ambas as épocas uma certa tendência para o exagero. Os produtos destas literaturas não nasceram de uma existência comunitária; procuram antes, por um maneirismo violento, mascarar a ausência de produtos literários válidos" (Benjamin 2013: 45).

O posicionamento de Benjamin, que evidencia as preocupações dos poetas do Barroco e do Romantismo com o instrumento linguístico e com a ressonância do lamento, não nos deixa dúvidas de existem tons do barroco nos poemas de Rainer Maria Rilke. Tal sugestão é uma maneira de justificar o diálogo que buscamos compreender com mais acuidade.

Se o fato de nos debruçarmos sobre os procedimentos de escrita poética de Ana Hatherly já é essencialmente fazer um estudo de sua poesia e de sua atividade crítica, encontraremos nesses textos mais um aspecto, que fora citado há pouco, trata-se do caráter lúdico da poesia hatherliana. Ana nos fala: "Para o poeta experimental não é já tanto o 
poema a obra criadora: o mais importante reside no conjunto de regras que o poeta a si próprio impõe, nas possibilidades desse conjunto de regras." (Hatherly 1976: 46). Estas palavras, retiradas do ensaio Da intertextualidade na poesia experimental, publicado na revista Colóquio/Letras, volume 34, nos incitam a refletir que um jogo, em sua estrutura, possui regras que lhe são próprias. A sua poesia como jogo programático, portanto, tem seus mecanismos próprios.

Quando se fala da poesia de Ana Hatherly, o jogo assume função primordial. Historicamente, a poeta busca este procedimento labiríntico no Maneirismo, que tinha como traço cultural a vida como representação. A partir de então surge a ligação entre representação e jogo. Diz a poeta no ensaio Uma experiência programática da poesia - labirintos portugueses dos séculos XVII e XVIII:

(...) havia mesmo um certo prazer no perder-se, no achar-se perdido no enigma, e essa concepção maneirista do mundo como um labirinto vai traduzir-se, particularmente na literatura, pela preferência dada à dificuldade de acesso ao entendimento imediato, pelo culto duma certa incompreensibilidade, atingida pela representação visual enigmática e pelo recurso de metáforas e associações paradoxais. (Hatherly 1995: 42)

(...) esta experiência da escrita como representação, ligada na sua origem a aspectos mágicos e propiciatórios, no período barroco mantém grande parte dessas características através da sua frequente assimilação do enigma, linguístico e visual, paradigma do labirinto do significado do mundo que, procura-se, tenha o maior número de leituras possível, fazendo apelo não só aos sentidos mas também à inteligência. (Hatherly 1995: 45)

Assim, por mais que tal forma de criação refletisse tão somente o contexto conflituoso que levava ao rebuscamento das formas, houve uma conversão em relação aos labirintos na arte e na poesia. Estar perdido em um labirinto poético significava, àquela época, estar perdido em si próprio. Contudo, no mesmo ensaio Hatherly reforça a ideia de que as representações labirínticas tinham uma função educativa, tendo em vista que era uma atividade intelectual, um estímulo aos sentidos. Desta maneira, na subvariação III- $A$, já citada, existe uma simplicidade aparente, que faz aumentar ainda mais as possibilidades de leitura, pela capacidade de síntese, convidando o leitor a retornar para a variação e desvendar mais os sentidos da subvariação.

No ensaio Questões de criatividade, Ana Hatherly vai às origens da palavra criatividade, que inicialmente difere-se da palavra criação e passou a constar nos dicionários recentemente, direcionando este vocábulo para a secularização de tal conceito. A poeta-ensaísta reflete:

Esta concepção da origem divina da inspiração, que seria o motor da criação antiga e romântica, e que se prolongou no conceito de alguns até os nossos dias, teve uma contrapartida 
num conceito clássico de inovação, em vez de criação, pois o culto dos mestres e a reverência pelas autoridades, no sentido culturalmente amplo do termo, não permitia o atrevimento da criação a partir do nada, implícito na criação divina. E quando, por exemplo, na música dos séculos XVI e XVII se fala em Invenção, o que se quer significar é simplesmente variação, variação sobre um tema. (Hatherly 2004: 92)

Esta passagem do ensaio nos diz muito do trabalho inventivo de Ana, primeiramente porque a poeta traça um caminho de origem naquilo que desenvolve em sua poética, e neste caso, temos a criação associada, de início, ao sagrado, para posteriormente ser secularizada. Em segundo lugar, porque tal secularização representa o ato criador à liberdade que o fazer artístico e poético requerem, e em terceiro lugar, porque a poeta recorre à etimologia da palavra para, em seguida, associar a criação à invenção musical. Nota-se que a própria ideia de invenção/criação está associada às variações poéticas e musicais. Partindo disso, pode-se pensar que realmente existe uma dimensão lúdica na elegia, ou no que a poeta irá denominar variações elegíacas, conforme escreve em alguns versos do livro Itinerários (2004), poema Um holograma estilhaçado: “É certo / entre a elegia e a nénia / numa sincronia de questões inúteis / a melancolia / cenicamente / veste-se de preto / órfã bagagem que ninguém reclama" (Hatherly 2004: 66-67). Isto significa que diante da inquestionabilidade da morte, que passa a ficar em segundo plano, a melancolia presente na elegia faz parte de um jogo, de uma dissimulação ou de uma encenação, mas que igualmente colocam em cena a representatividade. A respeito do jogo na era barroca, recorremos ao pensamento de Deleuze, que destaca em Leibniz o jogo dos princípios:

joga-se por excesso e não por falta de princípios; o jogo é dos próprios princípios, é de invenção de princípios. Trata-se, portanto, de um jogo de reflexão, de xadrez ou de damas, no qual a destreza (não o acaso) substitui a velha sabedoria e a velha prudência...é um jogo de preenchimento, no qual se conjura o vazio e já nada se restitui à ausência: é o Solitário invertido, de tal modo que se "preenche um buraco sobre o qual se salta", em vez de se saltar em um lugar vazio e de se suprimir a peça sobre a qual se salta, até que o vazio esteja completo. (Deleuze 2012: 120)

Esse jogo ao qual Deleuze se refere, que corresponde à ausência, não faz mais do que dar continuidade à experimentação de Ana Hatherly. Por isso pode-se dizer que a elegia é vista de uma outra maneira, nos levando inclusive a considerar que existe menos o caráter elegíaco nas variações poéticas de Ana, do que o jogo, o traço lúdico que permeia os seus versos. Contudo, não podemos desconsiderar o seu rigor técnico, pois Rilkeana é uma obra de escrita ética e generosa, haja vista uma exposição deliberativa da própria poeta, em seu gesto de apropriação dos poemas de Rilke. Relembrando que nisto não há problema algum, pois o ato criativo é integrante da estrutura do poema. 
Se concordamos com o que Deleuze tem refletido até então sobre aspectos do Barroco, podemos acrescentar o que diz no ensaio 0 que é o ato de criação?, pois nele afirma que "Um criador não é um ser que trabalha por prazer. Um criador faz apenas o que ele tem absoluta necessidade de fazer." (Deleuze 2015: 391). Hatherly nos mostrou anteriormente que no período barroco havia o prazer pelo jogo, o prazer em perder-se no labirinto, o que comprova o prazer que havia antes pelo trabalho de criação, que passa, sem dúvidas, pela necessidade. No mesmo ensaio, Questões de criatividade, Ana Hatherly prossegue:

\begin{abstract}
O verdadeiro criador artístico será então aquele que tem uma visão própria, uma visão outra, que difere <<criativamente>> do lugar-comum, da banalidade epigonal, aquele que sabe reinventar, subverter reorganizando os dados culturais disponíveis e consegue transmitir essa visão através de uma forma adequada. (Hatherly 2004: 94)
\end{abstract}

Nesse sentido, a poeta busca a sua originalidade por meio da reinvenção, para comprovar que determinados traços culturais continuam a ser transmitidos de forma diferenciada. Também em outros ensaios, Ana ressalta a importância do gesto criativo, que em nossa leitura, associamos ao jogo. A exemplo disto, citamos o que tem por título $A$ experiência crítica da poesia - I, II e III, do livro O espaço crítico - do Simbolismo à Vanguar$d a$ (1979) no qual, concisamente, Hatherly revela que "a criação é um acto lúdico repousando sobre a gratuidade, que ele (o poeta) aceita conscientemente, deliberadamente" (Hatherly 1979: 120). Percebemos de imediato que, além de o ato criador ser uma necessidade, conforme Deleuze afirma, há um espaço de abertura e consentimento da parte do criador, para expressar a sua liberdade, mantendo um compromisso com a cultura.

No livro A invenção da cultura, Roy Wagner destaca a importância do gesto inventivo. Para este antropólogo, há um intercâmbio cultural entre contextos convencionais e não convencionais, e a interatividade resutante dessa troca permite que cada contexto preserve sua singularidade, no decorrer da incessante influência que os contextos exercem entre si, e que comporta uma moralidade. Segundo ele,

Toda expressão dotada de significado, e portanto toda experiência e todo entendimento, é uma espécie de invenção, e a invenção requer uma base de comunicação em convenções compartilhadas para que faça sentido - isto é, para que possamos referir a outros, e ao mundo de significados que compartilhamos com eles, o que fazemos, dizemos e sentimos. Expressão e comunicação são interdependentes: nenhuma é possível sem a outra. (Wagner 2012: 109)

Compreendemos, assim, que a invenção tem a função de produzir novos sentidos, novas significações que são compartilhadas no âmbito cultural. A inventividade que faz parte da poesia de Ana Hatherly, passa exatamente por este processo que concebe a obra de arte e o poema a partir da troca simbólica entre culturas diferenciadas em inúmeros 
aspectos. Este conceito trazido por Roy Wagner também interliga-se à ideia de tradição que trazemos aqui, ao colocar em diálogo a poesia de Hatherly com a de Rilke, e com a de outros poetas. É através da associação entre diferentes contextos que a cultura se forma e faz com que o homem conheça a si próprio e o mundo em que vive, pois existe uma intrínseca relação entre invenção e experiência. Seguindo com Roy Wagner, leiamos a seguinte citação:

Todo pensamento, ação, interação, percepção e motivação humana pode ser entendida como uma função da construção de contextos lançando mão das associações contextuais de elementos simbólicos (semióticos). Como toda ação desse tipo, eficaz ou ineficaz, boa ou má, "correta" ou "incorreta" - se desenvolve mediante construções sucessivas, sua geração pode ser descrita como “invenção” ou “inovação". (Wagner 2012: 120-121)

O antropólogo faz aqui uma consideração importante, pois legitima o experimentalismo poético como práticas por meio das quais se leva em conta as experiências, a acrescentar a importância contextual, que nos traz à memória a Revolução dos Cravos. Naquele contexto, as palavras de Ana Hatherly podem nos esclarecer insistentemente o seu modo de inventar, em entrevista a Horácio Costa, em 2007.

O meu trabalho, como já referi, tem por sustentáculo o princípio de que a escrita é "uma pintura de signos". Também posso dizer que é uma aventura física e mental que aspira a uma forma de conhecimento, ou uma aventura que tenta atingir uma forma de perceber, de sentir e comunicar através de signos, que podem ser palavras ou não. Seja qual for o suporte, o instrumento, a técnica ou a matéria, desde que o objectivo final seja transmitir uma ou várias mensagens, aspira a uma forma de comunicação. A criação, essencialmente um acto lúdico de descoberta e de comunicação, se for conscientemente assumida como tal por quem a pratica, conduz a uma experimentação com um leque infinito de formas e sentidos muitas vezes inesperados. É por isso que eu defino o Poeta, no sentido lato do termo, como um "Calculador de Improbabilidades". (Costa 2007: 19)

$\mathrm{Na}$ entrevista percebemos as convergências entre o que Wagner pensa sobre a invenção, e o ato experimentalista de Ana, ao abranger o despertar dos sentidos do receptor da obra. Nesse caso, a inventividade da poeta perpassa pelo empenho mental, originado pela escrita e pela leitura, isto é, do cálculo das improbabilidades, além do empenho do corpo, fazendo com que leitor e poeta sejam unos na produção e recepção desses sentidos que fazem parte do contexto cultural português, àquela época, propício para o gesto vanguardista.

Em concordância com Deleuze, no que diz respeito à necessidade de criação, Roy Wagner pensa que "a necessidade de invenção é dada pela convenção cultural e a necessidade da convenção cultural é dada pela invenção.” (Wagner 2012: 141). Isto nos faz pensar 
que inventar constantemente é pensar de modo positivo em relação à tradição literária e cultural, de um modo geral, pois através da convenção da tradição já estabelecida é possível reconsiderar os novos modos de pensar, de escrever, de ler e de agir. A poesia de Ana, diante disto, sustenta-se no pensamento, em virtude da atividade mental a que nos desafia; na ação, não somente de escrita, mas também de leitura e de técnicas de produção; na interação, pois há um intercâmbio de sua poesia com outras culturas que divergem da sua, e no caso de nossa leitura, a cultura germânica; na percepção, porque dispensa a passividade do leitor que se vê desafiado pelos seus versos; e na motivação, que visa à transformação interior e exterior do mundo. Roy Wagner reflete que a motivação "é simplesmente a inércia ou a necessidade que se sente de ter de resolver as coisas de certo modo." (Wagner 2012: 145), ou modos, poderíamos dizer, se pensarmos no trabalho poético de Ana Hatherly, formado por múltiplas técnicas, de modo a contemplar a diversidade de comunicação e a estabelecer entre eles uma aproximação tensionada, assumindo, desta maneira, uma posição ética e estética no contexto poético da segunda metade do século passado.

Associar a poesia ao jogo, exige o conhecimento do poema como uma operação, segundo o pensamento da poeta, no ensaio Algures - o espço da significação, do mesmo livro ensaístico que fora citado:

O conceito de <<operação >> ligado à ideia de criação artística é ainda alargado pelos poetas experimentais, como já o fora pelos poetas de vanguarda do princípio do século, para a esfera da acção, ponto em que a correspondência entre a vida e a arte, o imaginário e o real cotidiano, a cultura e contracultura, a sociologia e a estética, para utilizar termos consagrados, coincidem numa tentativa de adequação entre a criação poética e as coordenadas temporais e espaciais dos homens que criam poesia. (Hatherly 1979: 53)

Assim, pode-se dizer que para Ana Hatherly o ato criativo envolve o jogo, com suas regras específicas; é algo original, tendo em vista a capacidade de transmissão de um aspecto cultural relevante para a sua transmissão e continuidade em dada cultura; e é uma operação, na qual culmina essa transmissão cultural por meio da ação, em suma, do gesto de escrita.

A poesia de Ana Hatherly, imbuída de ludicidade e rigor, na qual entrevemos traços barrocos, independente das formas poéticas utilizadas, também está preenchida de fantasia. O livro Rilkeana, que viabiliza inúmeras leituras e a exploração de diversos temas, especialmente a matafísica, e a existência humana, de forma geral, ao percorrer pelo caminho inventivo de releituras, nos permite associar o gesto criativo ao desejo fantasioso, conforme Freud esclarece no ensaio O poeta e o fantasiar (1908):

Deve-se dizer que quem é feliz não fantasia, apenas o insatisfeito. Desejos insatisfeitos são as forças impulsionadoras [Triebekräfte] das fantasias e toda fantasia individual é uma realização 
de desejo, uma correção da realidade insatisfatória. Os desejos que impulsionam são diferentes de acordo com o sexo, com o caráter e as relações da pessoa que fantasia. Mas, eles podem se agrupar, sem coação,de acordo com duas direções principais. Ou eles são desejos de ambição, que servem à elevação da personalidade, ou são eróticos. (Freud 2015: 271)

Do que Freud nos diz, podemos recolher o que diz respeito à insatisfação. $O$ ato criador surge de uma insatisfação ou inquietação, mas também ao preenchimento de um vazio interior, de uma falta. A criação, nesse prisma, é uma ação necessária, que impulsiona os desejos daquele que cria e os do receptor da criação. Na obra hatherliana, essa tendência se encaminha para o desejo erótico, no qual a palavra passa a exercer função sedutora no ato da leitura, na intencionalidade de se atingir o divino, para subverter tal ordem tematizando a impossibilidade amorosa. Freud salienta o seguinte:

Não deixemos de retornar aos tipos de poesia, na qual devemos entrever não a criação livre, mas o trabalho com um material já conhecido e pronto. Também aqui o poeta mantém uma parcela de autonomia, que se expressa na escolha dos temas e na frequente e considerável modificação dos mesmos. (Freud 2015: 275)

A criação e o fantasiar sendo equivalentes, portanto, nos remetem para a plagiotropia, principal aspecto do fazer poético de Ana Hatherly aqui posto em evidência, pois este procedimento possui como matéria principal um material conhecido e pronto, ou seja, os poemas de Rainer Maria Rilke, textos da tradição que formam também a tradição poética portuguesa. O fantasiar, objeto de estudos freudianos, possui a abertura do gesto criativo, mas também proporciona a autonomia não somente de Ana Hatherly em relação a Rilke, mas dos poetas portugueses modernos e contemporâneos que o leram e continuam a ler.

Optar pela escrita em variações, é mergulhar no labirinto criado pela poeta. Na poesia portuguesa, podemos perceber que Ruy Belo, por exemplo, escreve por meio delas em sete variações sobre o poema “O jogador do pião" no livro Boca Bilingue (1966), já na música, fonte primeira de onde Hatherly retira suas principais influências para a escrita poética, citemos, para fins de exemplificação, as Bachianas Brasileiras, do compositor Heitor Villa-Lobos. Contemporaneamente, também o pianista e compositor brasileiro André Mehmari² escreveu as Variações Villa-Lobos (2006) e Valsa-Variação sobre Tico-Tico no Fubá (2000). Percebemos, de antemão, uma sequência de influências que contemplam as composições brasileiras e nos fazem perceber nas produções artíticas atuais a permanência por esse tipo de criação. Silvana Oliveira, professora de Literatura Portuguesa da Universidade Federal de Minas Gerais, em sua leitura de O Mestre, incia seu texto da seguinte maneira: "Alguém já disse que em arte há sempre mais ou menos nítida uma memória e que cada texto ou quadro, escultura ou filme põe em circulação, de forma sempre diferida, um repertório que estabelece com a tradição um diálogo, muitas vezes sob forma de variação" 
(Oliveira, 2015, p. 179). Neste artigo, a autora sintetiza traços primordiais da escrita hatherliana, como a memória recuperada de um passado integralizador da tradição histórica portuguesa, a perspectiva interartística, e o diálogo em variação.

Como leitora atenta da obra poética de Ana, em outro ensaio intitulado Palavra-imagem: a poesia portuguesa contemporânea, Silvana também aponta traços gerais da poesia experimental, que se relacionam ao que diz sobre variação: "é possível notar na poesia experimental portuguesa a vocação para a exploração da materialidade do signo linguístico, manifesta em jogos de palavras, trocadilhos, aliterações, hipérboles, antíteses, bem como em jogos conceituais e metafóricos, na busca de isomorfismo" (Oliveira, 1997: 244), e mais adiante: "os textos de poesia experimental aproveitam do acervo da tradição as soluções técnico-formais e temáticas, relendo-as mais ou menos criativamente, em tom de paralelo ou de contra-canto" (Oliveira 1997: 246).

Além das origens musicais da escrita em variações, a poeta buscará este paradigma também nas formas labirínticas barrocas. A variação está intimamente imbrincada à ideia de poesia programática que se executava naquela época. Neste âmbito, a maior influência daquele período era a Arte Poética, de Juan Diaz Rengifo, cujo programa de labirintos poéticos consistia nesta divisão: Labirintos de Versos, Labirintos de Letras, Labirintos Cúbicos e Formas Mistas. Tais divisões ainda subdividem-se em outras especificidades. Este programa será uma referência para Ana Hatherly, que inspirará a criação do Programa de Estruturas Poéticas, inserido na revista Operação-2 e, posteriormente, no texto-piloto da Poesia Experimental Portuguesa e na antologia Um calculador de improbabilidades. No ensaio Labirintos poéticos barrocos - uma plataforma de ponderação, Ana Hatherly nos ensina sobre as formas labirínticas:

O aspecto que todos os labirintos poéticos do barroco têm em comum - seja qual for o seu tipo, forma, tamanho, língua ou mensagem textual - é o seu programa, que inclui a obrigatoriedade da leitura múltipla, implícita em sua estrutura, em alguns casos claramente indicada no próprio texto ou no título. Esta característica essencial da forma é confirmada pelas Artes Poéticas e pelos comentários produzidos na época, que acentuam a sua natureza de percurso dificultoso, inicialmente ligado à ideia de espaço oculto, de prova, de iniciação. Os labirintos poéticos são, portanto, composições que implicam um programa, que é estabelecido de acordo com um cânone, um conjunto de regras fixas que devem ser conhecidas tanto do autor como do leitor, a fim de que este possa decifrar, além da mensagem fornecida pelas palavras do texto, a mensagem implícita na correlação existente entre texto e estrutura, onde a profunda mensagem simbólica reside.

(...)

Se me pedissem para descrever esses textos duma maneira simples e básica, independentemente da sua origem mais que mágica ou religiosa, eu diria que os labirintos poéticos são composições em que a característica predominante é a sua natureza enigmática, de desafio. No mais antigo sentido da palavra, são adivinhas, textos codificados para serem decifrados 
por um destinatário, contendo uma mensagem particular, independentemente da língua ou do sistema de línguas neles usados e qualquer que seja o tipo de mensagem transmitida. A sua natureza enigmática reside nos níveis de significação neles ocultos e sobrepostos e no correspondente número de leituras que oferecem, quer a sua intenção seja mágica, mística, laudatória ou simplesmente lúdica. (Hatherly 1995: 106-108)

Desvela-se, agora, um procedimento de escrita, um norteamento para a poesia de Ana Hatherly, que certamente será facilitador da leitura de Rilkeana. Não é possível afirmar concretamente até que medida a poeta lança mão de seu programa poético, ou arte poética, se assim quisermos chamar, todavia, é de conhecimento tal processo criativo, que envolve esfoço de leitura para desvendar seus enigmas, que nunca estão revelados completamente, apesar da existência de um roteiro que facilita os caminhos de leitura. 0 programa, quando inserido na obra, é um complemento à leitura do poema, sendo que este pode acompanhá-lo ou não, ficando a critério do leitor utilizá-lo ou perder-se no enigma, pois seu uso não interfere no grau de dificuldade que a leitura poética exige. Mantemos, deste modo, o olhar atento no que a poeta escreve em carta enviada a Elfriede Engelmeyer sobre a origem do livro Rilkeana, salientando que apesar do aspecto labiríntico assumido pelos poemas, a obra em si não apresenta nenhum programa que oriente a sua leitura:

...as minhas Variações Elegíacas, embora tenham sido motivadas pelo texto rilkeano e incluem alguns fragmentos dele, além do primeiro verso de cada uma das Elegias, são bastante independente delas. Não são nem quererm ser paráfrase. São eco, mas um eco transfigurado pela minha óptica, pela óptica do meu tempo, da minha vida, da minha luta com os Anjos, com esses <<anjos que já não me sorriem»>, como eu disse na minha Idade da Escrita; esses anjos que em criança eu <<via>> nas nuvens, segundo consta das minhas Tisanas...

Quando dei por concluídas, as minhas $<<$ Rilkeanas $>>$ surpreenderam-me. Levei muito tempo a escrevê-las e a pensar nelas. Agora começo a desligar-me. Repare que agora falo dessas Variações no plural. Uma destas noites quando estava deitada na minha cama pensando nesses textos, de repente compreendi que a edição que agora vai sair na Assírio \& Alvim deve designar-se assim, por duas razões: primeiro, para a distinguir da versão policopiada; segundo porque, se eu conseguir, essa edição deve conter, além dos estudos introdutórios, alguns poemas - visuais ou não - sobre os <<Sonetos de Orfeu >>. Não acha que tenho razão? (Hatherly 2004: 126)

Constata-se que nem na versão de 1998, sob o título Variações Elegíacas, nem na versão final publicada pela Assírio \& Alvim, não foram iseridos os poemas-visuais, contudo, este aspecto, que tem sido nosso ponto de reflexão até o presente momento, é preponderante nesta obra da autora. Por herança barroca, ainda convocamos o estudo recente de Pedro Sena-Lino, para quem o Barroco é uma função na obra da artista, o 
que de certo modo corrobora o que Deleuze já tomara como ponto de estudo. Para ele, a ancoragem do experimentalismo de Ana ao Barroco se faz investigando-o, utilizando o Barroco como forma e operacionalizando o Barroco. Cito Sena-Lino:

Ana Hatherly não apenas operacionalizou o Barroco, também recuperando elementos rupturais do Barroco Histórico à sua época (fruto do seu trabalho arqueológico mas também arte-operativo), e assim o cumprindo; a sua obra cumpre um programa experimental total, ao trabalhar a forma como desfragmentação da língua, dos símbolos, e a língua como desfragmentação dos códigos. Tornando não apenas o Barroco mas a história literária não apenas um corpo conceptual, referencial, tradição, mas também e sobretudo função. Ao operacionalizar o Barroco, Ana Hatherly chega aos limites da história literária, para criar uma nova relação entre signo e sentido. (Sena-Lino: 2017)

Sugere-se, portanto, que em Rilkeana o Barroco não é apenas função, no sentido de operacionalizá-lo, torná-lo procedimento de escrita, mas acrescentamos que se trata de uma função inserida no movimento plagiotrópico, haja vista que os traços barrocos possuem o intuito de reler e recriar. Existe um caráter inventivo, lúdico, que culmina na atividade de releitura, e que necessariamente precisa ser levado em consideração. Esta obra hatherliana é uma obra barroca, cujas dobras conduzem o leitor ao infinito, pelas reflexões suscitadas e pelos procedimentos únicos utilizados pela escritora. Encerro este artigo com uma passagem pelo ensaio de Pedro Serra sobre Fibrilações (2005), que retoma a epígrafe desta seção: "A poesia como jogo, paradigma tão caro a Ana Hatherly; poesia em que "o brinquedo somos nós", imagem em que não deixará de reverberar a magistral lição pessoana, do Fernando Pessoa que, sendo poeta, é especialista em resumos, como aquele de uma "Autopsicografia" que termina com o "lúdico coração" que somos, justamente" (Serra 2015: 151).

\section{NOTAS}

* Matthews Cirne é doutorando bolsista (CNPq) do Programa de Pós-Graduação em Letras Vernáculas (Literaturas Portuguesa e Africanas) da Universidade Federal do Rio de Janeiro (UFRJ). É membro do Grupo de Estudos e Pesquisas em Literaturas de Língua Portuguesa (GEPELIP/UFAM) e do grupo de pesquisa Escritas do Corpo Feminino (UFRJ).

\footnotetext{
${ }^{1}$ https://gulbenkian.pt/museu/artist/ana-hatherly/
}

${ }^{2}$ andremehmari.com.br 


\section{BIBLIOGRAFIA}

Aristóteles (2015), "Poética", in O belo autônomo: textos clássicos de estética, org. de Rodrigo Duarte, Belo Horizonte, Autêntica Editora, Crisálida.

Belo, Ruy (1966), Boca Bilingue, Lisboa, Edições Ática.

Compagnon, Antoine (1996), O trabalho da citação, trad. de Cleonice P. B. Mourão, Belo Horizonte, EDUFMG.

Costa, Horácio (2017), "Entrevista com Ana Hatherly", in Revista Via Atlântica. n.11. 2007, Dossiê Ana Hatherly, <https://www.revistas.usp.br/viaatlantica/article/ view/50659/> (último acesso em: 11/11/2017).

Deleuze, Gilles (2012), A Dobra: Leibniz e o barroco, trad. de Luiz B. L. Orlandi, Campinas, Papirus Editora.

-- (2015), “O que é o ato de criação?”, trad. de João Gabriel Alves Domingos, in: O belo autônomo: textos clássicos de estética, org. de Rodrigo Duarte, Belo Horizonte, Autêntica Editora, Crisálida.

Freud, Sigmund (2015), "O poeta e o fantasiar", trad. de Ernani Chaves, in O belo autônomo: textos clássicos de estética, org. de Rodrigo Duarte, Belo Horizonte, Autêntica Editora, Crisálida.

Gastão, Ana Marques (2004), "Palavras que riem", in Interfaces do olhar - uma antologia crítica, uma antologia poética, Lisboa, Roma Editora.

Gomes, Maria dos Prazeres (1993), Outrora agora: Relações dialógicas na poesia portuguesa de invenção, São Paulo, EDUC.

Hatherly, Ana (1979), "A experiência crítica da poesia - I, II e III”, in O espaço crítico - do Simbolismo à Vanguarda, Lisboa, Editorial Caminho.

-- (1979), "Algures - O espaço da significação", in O espaço crítico - do Simbolismo à Vanguarda, Lisboa, Editorial Caminho.

-- (2004), "Carta a Elfriede Engelmeyer sobre a génese de Rilkeana”, in Interfaces do olhar - uma antologia crítica, uma antologia poética, Lisboa, Roma Editora.

-- (2004), "Questões de Criatividade", in Interfaces do olhar - uma antologia crítica, uma antologia poética, Lisboa, Roma Editora.

-- (1976), “Da intertextualidade na poesia experimental”, in Colóquio/Letras, n. 34, Lisboa, Fundação Calouste Gulbenkian.

-- (1995), "Uma experiência programática da poesia portuguesa - labirintos portugueses dos séculos XVII e XVIII”. in: A casa das musas: uma releitura crítica da tradição. Lisboa, Editorial Estampa.

-- (1995), “Labirintos poéticos barrocos: uma plataforma de ponderação”, in: A casa das musas: uma releitura crítica da tradição. Lisboa, Editorial Estampa.

Oliveira, Silvana Maria Pessoa de (2015), "Sobre o amor em O Mestre, de Ana Hatherly", in Encontros com Ana Hatherly, org. de Ida Alves e Rogério Barbosa, Rio de Janeiro, Oficina Raquel. 
-- (2017), "Palavra-imagem: a poesia portuguesa contemporânea", in Boletim do CESP, v. 17, n.21. jan. / dez. 1997, <http://www.periodicos.letras.ufmg.br/index.php/cesp/ article/view/4610> (último acesso em: 10/05/2017).

Pereira, Paulo (1997), "As dobras da melancolia - o imaginário barroco português", in Ávila, Affonso, Barroco: teoria e análise, São Paulo, Perspectiva, Belo Horizonte Companhia Mineira de Metalurgia e Mineração.

Salgado, Marcus Rogério (2015), "As metamorfoses da escrita: Constelações de palavras e imagens na obra plástica de Ana Hatherly", in Encontros com Ana Hatherly, org. de Ida Alves e Rogério Barbosa, Rio de Janeiro, Oficina Raquel.

Sena-Lino, Pedro (2017), "Do Barroco como função em Anagramático de Ana Hatherly", in Plural Pluriel: Revue des cultures de langue portugaise, n. 16. 2017: Le mains intelligentes de Ana Hatherly, <http://www.pluralpluriel.org/index.php/revue/ issue/view/12> (último acesso em 05/10/2017).

Serra, Pedro (2015), “FIBRILAÇÕES ou a febril ação - A figura do 'coração tardio' em Ana Hatherly", in Encontros com Ana Hatherly, org. de Ida Alves e Rogério Barbosa, Rio de Janeiro, Oficina Raquel.

Silva, Maria Augusta (2017), "Ana Hatherly entrevistada por Maria Augusta Silva", in Casal das Letras (Entrevista realizada em maio / 2000), <http://www.casaldasletras.com/ Textos/ANA\%20HATHERLY.pdf> (último acesso em 30/10/2017).

Silva, Rogério Barbosa da (2011), "Invenção do futuro, releituras do passado: o imaginário poético português na perspectiva da poesia experimental", in Poetas que interessam mais: leituras da poesia portuguesa pós-Pessoa, Rio de Janeiro, Beco do Azougue.

Wagner, Roy (2012), A invenção da cultura, São Paulo, Cosac Naify. 